\title{
KETEPATAN RESELEKSI DIAGNOSA DAN KODE UTAMA BERDASARKAN ATURAN MORBIDITAS PEMBIAYAAN JAMINAN KESEHATAN INA-CBGS
}

\author{
Linda Widyaningrum \\ APIKES Citra Medika Surakarta \\ linda.ningrum@ymail.com
}

\begin{abstract}
One of the indicators the quality of hospital services can be known through medical records. The quality of hospital services is based on regulation of the Minister of Health of the Republic of Indonesia Number 269 / Menkes / Per / III / 2008. According to the PERMENKES Medical Record is the file containing the notes, checks and other measures of treatment given to the patients. Qualified medical record can be seen from the accuracy in writing main diagnostic and diagnosis codes. This study aimed to analyze the relationship precision diagnostics rules and the main code of inpatient medical record document, based on the rules for financing health insurance morbidity rates of INA-CBGS at Surakarta Prof. Dr. Soeharso Orthopaedic Hospital in May 2015. The population in this study is medical records documents of inpatients of the National Health Insurance in May 2015. The number of the documents are 30 documents of $2^{\text {nd }}$ class in the hospital. In this study, to collect the data, the writer uses checklist to diagnose and analyze the accuracy of the diagnosis rules and the main code and of INA-CBGs financing. The test used in this study is Chi Square. The accuracy of primary diagnosis and primary diagnosis code of Surakarta Prof. Dr. Soeharso Orthopaedic hospital is in good categories. Where the main diagnostic accuracy is $100 \%$ and primary diagnosis code is $93.3 \%$. Health insurance financing that uses INA CBGs software can affect the accuracy of financing cost. There is a significant relationship between the accuracy of the rules of Diagnosis and Main Diagnosis Codes Document Medical Record system using financing. The results of significant value is 0.00 , and $p<a(0.05)$.
\end{abstract}

Keywords: Rules of Diagnosis and Main Diagnosis Code, financing cost, INA CBGs

\begin{abstract}
Abstrak
Salah satu indikator mutu pelayanan tersebut dapat diketahui melalui rekam medis dimana rekam medis berdasarkan peraturan Menteri Kesehatan Republik Indonesia nomor 269/MENKES/PER/III/2008 adalah berkas yang berisikan catatan, pemeriksaan, pengobatan tindakan lain yang diberikan kepada pasien. Rekam medis yang berkualitas dapat dilihat dari keakuratan menuliskan diagnose utama dan kode diagnosa. Penelitian ini bertujuan untuk menganalisa hubungan ketepatan reseleksi diagnosa dan kode utama dokumen rekam medis rawat inap berdasarkan aturan morbiditas terhadap pembiayaan jaminan kesehatan tarif INA-CBGS di Rumah Sakit Ortopedi Prof. Dr. Soeharso Surakarta Bulan Mei Tahun 2015. Populasi dalam penelitian ini adalah Dokumen rekam medis pasien rawat inap Jaminan Kesehatan Nasional pada bulan Mei 2015 kelas 2 dengan jumlah 30 dokumen dokumen. Pada penelitian ini, alat pengumpulan data yang digunakan adalah cheklist untuk menganalisa ketepatan reseleksi diagnose dan kode utama serta pembiayaan INA-CBGs. Uji yang digunakan adalah Chi Square. Keakuratan diagnosa utama dan kode diagnosa utama rumah sakit Ortopedi Prof Dr.Soeharso Surakarta masuk kategori baik. Dimana keakuratan diagnosa utama 100\% dan kode diagnosa utama 93.3\%. Pembiayaan Jaminan kesehatan memakai software INA CBGs dimana keakuratan kode mempengarui biaya pembiayaan. Ada hubungan yang signifikan Ketepatan Reseleksi Diagnosa Dan Kode Utama Diagnosa Dokumen Rekam Medis Dengan Pembiayaan dengan nilai signifikan 0,00, dan $\mathrm{p}<\mathrm{a}(0,05)$.
\end{abstract}

Kata Kunci : Reseleksi diagnose dan kode utama, Pembiayaan, INA-CBGS 


\section{PENDAHULUAN}

Kesehatan merupakan hal yang sangat penting agar manusia dapat bertahan hidup dan melakukan aktivitas. Pentingnya kesehatan ini mendorong pemerintah untuk mendirikan layanan kesehatan, agar masyarakat dapat mengakses kebutuhan kesehatan. Layanan kesehatan salah satu jenis layanan publik merupakan ujung tombak dalam pembangunan kesehatan masyarakat. Salah satu layanan kesehatan yaitu rumah sakit.

Rumah sakit adalah bagian penting dari suatu sistem kesehatan, karena rumah sakit menyediakan pelayanan kuratif komplek, pelayanan gawat darurat, berfungsi sebagai pusat rujukan dan merupakan pusat alih pengetahuan dan keahlian teknologi. Rumah sakit harus senantiasa meningkatkan mutu pelayanan sesuai dengan harapan pelanggan yang dapat dilakukan melalui peningkatan kualitas kerja. Upaya peningkatan mutu pelayanan kesehatan sangat tergantung dari tersedianya data dan informasi yang akurat, terpercaya dan penyajian yang tepat waktu. Upaya tersebut hanya dapat dilaksanakan apabila faktor manusia sebagai pemeran kunci dalam pengelolaan rekam medis dan informasi disiapkan secara seksama dan lebih profesional (Hatta, 2010). Salah satu indikator mutu pelayanan tersebut dapat diketahui melalui rekam medis diman rekam medis berdasarkan peraturan Menteri Kesehatan Republik Indonesia nomor 269/MENKES/PER/III/2008 adalah berkas yang berisikan catatan, pemeriksaan, pengobatan tindakan lain yang diberikan kepada pasien. Rekam medis yang berkualitas dapat dilihat dari keakuratan menuliskan diagnose utama dan kode diagnosa.

Keakuratan penentuan diagnosis utama dan kode diagnosa sangat mempengaruhi kualitas data statistik penyakit dan masalah kesehatan serta pembayaran biaya kesehatan dengan sistem Case-Mix/ (INACBGs). Pada awalnya sistem tersebut dinamakan Indonesia Case Grops (INA-DRGs) namun karena lisensi maka berganti nama menjadi (INA-CBGs) pada 1 Oktober 2010. Sistem pembayaran dengan tarif (INA-CBGs) dimana pemberi pelayanan kesehatan akan menerima sejumlah imbalan yang besarnya sesuai dengan diagnosis utama penyakit. Penentuan diagnosa yang salah akan mengakibatkan kode diagnosa tidak tepat dan mengakibatkan pembiayaan tarif INA-CBGs yang tidak akurat. (Hufinan 1994).
Penentuan atau reseleksi diagnosa utama merupakan penentuan suatu diangnosa utama berdasarkan kondisi yang paling relevan selama perawatan (ICD:2004). Berdasarkan Peraturan Menteri Kesehatan Nomor 377 tahun 2007 tentang Kompetensi Perkam Medis dan Informasi Kesehatan salah satu koptesensi rekam medis adalah klasifikasi dan kodefikasi penyakit, masalah-masalah yang berkaitan dengan kesehatan dan tindakan medis. Dalam penentuan kode dignosa seorang coder wajib memperhatikan kondisi mana yang seharusya menjadi diagnose utama berdasarkan aturan morbiditas MB1-MB2 pada ICD X vol 2. Dalam hal ini komunikasi coder dan dokter sangat berperan dalam penentuan kondisi utama.

Rumah Sakit Ortopedi Prof. Dr. R. Soeharso Surakarta adalah rumah sakit tipe A Pendidikan Kolegium Ilmu Ortopedi dan Traumatologi Indonesia yang merupakan rujukan nasional. Rumah Sakit Ortopedi Prof Dr.R. Soeharso Surakarta untuk meningkatkan kepuasan pelanggan atau pemakai jasanya salah satunya melalui peningkatan keakuratan kode diagnosa. Pengkodean dignosa penyakit di Rumah Sakit Ortopedi Prof Dr.R.Soeharso Surakarta menggunakan ICD-X (lhe International Statistical Classification of Diseases and Related Health Problems) sedangkan kode tindakan ICD 9-CM (International Classification of Diseases, Ninth Revision, Clinical Modification).

Skema pembiayaan pasien asuransi di rumah sakit Ortopedi Prof Dr.Soeharso Surakarta yaitu dengan menggunakan sistem casemix dengan paket INACBGs dimana diagnosis utama menjadi acuan untuk menghitung biaya pelayanan. Dalam penentuan tarif klaim pasien di rumah sakit Ortopedi Prof Dr.Soeharso Surakarta didasarkan atas diagnosa akhir yang nantinya oleh petugas rumah sakit dientry dalam software INA-CBGs dan keluar dalam bentuk grouping. Oleh karena itu diagnosa akhir dan kode diagnosa yang dientry sebagai penentu dari besarnya klaim INA-CBGs. Skema ini sama dengan sistem pembiayaan di RSUD Salatiga berdasarkan penelitian Sudra (2010) yang berjudul Tinjauan Pembiayaan Diagnosa Hypertensi berdasarkan INA-CBGs.

\section{METODE}

Jenis penelitian yang digunakan dalam penelitan ini adalah analitik korelasi. Populasi dan sampel penelitian ini objeknya adalah dokumen rekam 
medis rawat inap bulan Mei 2015 pasien JKN kelas 2 dengan jumlah 30 dokumen rekam medis rawat inap. Instrumen yang digunakan pedoman observasi berupa check list. Pengumpulan data dilakukan berupa observasi. Analisis data yaitu analisis univariat dan analisis bivariat ini menggunakan chi square.

\section{HASIL}

\section{Prosentase Keakuratan Diagnosa Utama} Berdasarkan Reseleksi Kode

Tabel 1 Prosentase Keakuratan Diagnosa Utama

\begin{tabular}{|c|c|c|c|}
\hline Keakuratan & & Jumlah & Prosentase \\
\hline $\begin{array}{l}\text { Keakuratan } \\
\text { Diagnosa } \\
\text { Utama }\end{array}$ & Baik & 30 & $100 \%$ \\
\hline Total & & 30 & $100 \%$ \\
\hline
\end{tabular}

Pada Tabel 1 diatas dapat diketahui bahwa diagnosa utama dari 30 dokumen (100\%) akurat.

2. Prosentase Keakuratan Kode Diagnosa Utama Berdasarkan Reseleksi Kode

Tabel 2 Prosentase Keakuratan Kode Diagnosa Utama

\begin{tabular}{lll}
\hline \multicolumn{1}{c}{ Keakuratan } & \multicolumn{1}{c}{ Jumlah } & \multicolumn{1}{c}{ Prosentase } \\
\hline Akurat & 28 & $93.3 \%$ \\
Tidak Akurat & 2 & $6.7 \%$ \\
\hline Total & 30 & $100 \%$ \\
\hline
\end{tabular}

Pada tabel 2 diatas dapat diketahui bahwa kode diagnosa 27 dokumen (90\%) akurat dan 3 dokumen (10\%) tidak akurat. Ketidakakuratan terdapat pada kode penyakit Pertrochanteric fracture dengan infeksi dan, Osteoblastoma (Giant Cell Tumor Of The Bone).

3. Prosentase Pembiayaan berdasarkan Kode Diagnosa

Tabel 3 Pembiayaan berdasarkan Kode Diagnosa

\begin{tabular}{|c|c|c|}
\hline Keakuratan & Jumlah & Prosentase \\
\hline Tetap & 29 & $96.67 \%$ \\
\hline Tidak Tetap & 1 & $3.33 \%$ \\
\hline Total & 30 & 100 \\
\hline
\end{tabular}

Pada tabel 3 diatas dapat diketahui 29 kode (96,67\%) diagnosa peneliti dan rumah sakit tetap artinya kode yang diinputkan ke Software INA CBGS tidak mengalami perubahan dan perbedaan. Terdapat 1 kode $(3,335)$ diagnosa yang mengalami perubahan atau tidak tetap yaitu terdapat pada diagnosa Pertrochanteric fracture dengan infeksi dimana rumah sakit memberikan kode S72.10 sedangkan peneliti memberikan kode S72.11 karena untuk fracture dengan infeksi.

\section{Hubungan Keakuratan Reseleksi Diagnosa} Dan Kode Diagnosa dengan pembiayaan

Pada tabel 4 diatas dapat diketahui bahwa hasil uji statistik Chi-Square didapatkan hasil bahwa nilai signifikansi adalah 0,00 , sehingga $\mathrm{p}<\mathrm{a}(0,05)$. Oleh karena itu, Ho ditolak dan Ha diterima yang artinya ada hubungan antara Reseleksi Diagnosa Dan Kode Diagnosa dengan pembiayaan.

\section{PEMBAHASAN}

\section{Keakuratan Diagnosa Utama Berdasarkan}

\section{Reseleksi Kode}

Keakuratan penentuan diagnosa utama di rumah sakit ortopedi Prof.Soeharso Surakarta masuk kategori baik dimana seluruh dokumen rekam medis pasien rawat inap akurat dalam penentuan diagnosa utama. Penentuan diagnosa utama didasarkan pada reseleksi diagnosa dimana terdapat diagnosa tambahan, diagnosa komplikasi, tindakan serta pelayanan spesialistik yang telah diperoleh oleh pasien selama masa perawatan.

Penentuan diagnosa utama di rumah sakit ortopedi Prof.Soeharso Surakarta merupakan diagnosa yang lebih menjadi perhatian bagi tenaga medis untuk ditangani. Hal ini sesuai dengan Shofari (2002) dimana diagnosa utama merupakan diagnosa yang paling relevan dalam masa perawatan dan ditegakan pada akhir episode pelayanan setelah dilakukan pemeriksaan yang lebih mendalam. Penentuan diagnosa utama merupakan tanggung jawab dokter yang merawat pasien selama masa perawatan, diamana dari diagnosa yang telah ditetapkan oleh dokter merupakan salah satu peran penting dalam keakuratan kode diagnosis yang akan mempengarui sistem pembiayaan.

2. Keakuratan Kode Diagnosa Utama Berdasarkan Reseleksi Kode

Keakuratan kode diagnosa di rumah sakit sakit ortopedi Prof.Soeharso Surakarta berdasarkan 
sampel yang berjumlah 30 dokumen (93.3\%) dengan kategori baik.

Ketidakauratan kode diagnosa terdapat 2 dokumen $(6.7 \%)$ yaitu dengan diagnosa Pertrochanteric fracture dengan infeksi dan, Osteoblastoma (Giant Cell Tumor Of The Bone).

Berikut adalah perincian ketidakakuratan kode diagnosa :

$$
\begin{array}{ll}
\text { Kode Rumah Sakit } & \text { : S72.10 } \\
\text { Kode Peneliti } & : \text { S72.11 } \\
\text { KU } & \text { : Pertrochanteric fracture } \\
& \text { dengan infeksi }
\end{array}
$$

Kesalahan kode Rumah Sakit dikarenakan kesalahan pembacaan informasi penunjang yang seharusnya luka tertutup namun dikode luka terbuka. Berdasarkan aturan WHO (2004) untuk angka 0 berarti kondisi luka terbuka, sedangkan angka 1 pada kondisi luka tertutup. Hasil review informasi penunjang menunjukkan bahwa pada kondisi luka tertutup sehingga kode yang akurat adalah S72.11.

Ketidakakuratan yang ke 2 adalah kode penyakit Osteoblastoma (Giant Cell Tumor Of The Bone).

Berikut adalah perincian ketidakakuratan kode diagnosa :

Kode Rumah Sakit : D16.9 M8031/3

Kode Peneliti : D16.9 M9200/0

Kesalahan pengkodean antara kode Rumah Sakit dan peneliti terletak pada penentuan kode morfologi. Pengkodean neoplasma terdiri dari kode morfologi dan kode topografi. Lead Term kode adalah Osteoblastoma didapatkan hasil M9200/0 dimana kode morfologi sebagai penentu behavior dari neoplasma yang digunakan untuk menentukan kode topografi dalam tabel neoplasma. Osteoblastoma memiliki kode behavior $/ 0$ artinya neoplasma tersebut bersifat benign. Berdasarkan wawancara ketidakakuratan ini dikarenakan tidak ada pengaruh dengan pembiayaan INA CBGs karena yang memiliki peran penting adalah kode dari topografi yaitu D16.9. Menurut teori kode morfologi merupakan kode penentu untuk menentukan kode topografi karena didalam kode morfologi terdapat kode behavior yang akan digunakan sebagai penentu kode topografi.

\section{Pembiayaan Kode Diagnosa Berdasarkan Ina CBGs}

Pembiayaan kode diagnosa berdasarkan Ina CBGs terdapat 1 kode diagnosa yang pembiayaanya mengalami perubahan atau tidak tetap. Kode diagnosa terdapat pada Pertrochanteric fracture dengan infeksi dimana jika dilakukan groping dalam sistem INA CBGs antara kode S72.11 dengan S72.10 mengalami perbedaan jumlah nominal. Hal ini sesuai dengan teori bahwa keakuratan kode berpengaruh pada pembiayaan. Secara rinci dapat dijelaskan oleh Hatta (2010) yaitu:

Ketepatan kode diagnosis berguna untuk :

a. Mengindeks pencatatan penyakit dan tindakan disarana pelayanan kesehatan

b. Masukan bagi sistem pelaporan diagnosis medis

c. Memudahkan proses penyimpanan dan pengambilan data terkait diagnosis karakteristik pasien

d. Bahan dasar pengelompokan CBGs untuk sistem penagihan pembayaran biaya pelayanan.

e. Pelaporan nasional morbiditas dan mortalitas, tabulasi data pelayanan kesehatan bagi proses evaluasi perencanaan pelayanan medis

f. Menentukan bentuk pelayanan yang harus direncanakan dan dikembangkan sesui kebutuhan zaman.

g. Analisi pelayanan kesehatan

h. Penelitian epidemiologi dan klinis

Hasil penelitian ini sesui dengan hasil penelitian beberapa peneliti Hapsari (Aulia), 2014 dimana kasus tindakan sectio cecarea yang didapatkan hasil bahwa ketidakakuratan kode diagnosa berpengaruh terhadap pembiayaan claim INA CBGs.

\section{SIMPULAN}

1. Keakuratan diagnosa utama dan kode diagnosa utama rumah sakit Ortopedi Prof Dr.Soeharso Surakarta masuk kategori baik. Dimana keakuratan diagnosa utama $100 \%$ dan kode diagnosa utama $93.3 \%$.

2. Pembiayaan Jaminan kesehatan memakai software INA CBGs dimana keakuratan kode mempengarui biaya pembiayaan. 
3. Ada hubungan yang signifikan Ketepatan Reseleksi Diagnosa Dan Kode Utama Diagnosa Dokumen Rekam Medis Dengan Pembiayaan dengan nilai signifikan 0,00 , dan $\mathrm{p}<\mathrm{a}(0,05)$.

\section{DAFTAR PUSTAKA}

Departeme Kesehatan RI. 2006. Pedoman Pengelolahan Rekam Medis Rumah Sakit di Indonesia. Jakarta : Depkes RI.

Hatta, G. R.2010. Pedoman Manajemen Informasi Kesehatan Di Sarana Pelayanan Kesehatan Edisi Revisi. Jakarta: Universitas Indonesia.

Huffman, E. K. 1994. Health Information Management. Illions: Physicians Record Company.

LaTour \& Shirley E. M. 2010. Health Information Mangement Concepts, Principies, and practice. Third Edition. Chicago Illions: American Health Information Management Association (AHIMA)

Manlak. 2012. Pembiyaan Jamkesmas. Yogyakarta: Rineka Cipta.
Menteri Kesehatan RI. 2007. Keputusan Menteri Kesehatan Republik Indonesi Nomor.377/ MENKES/SK/III/2007 tentang Standar Profesi Perekam Medis dan Informasi Kesehatan. Jakarta: DepKes RI.

Menteri Kesehatan RI. 2008. Peraturan Menteri Kesehatan Republik Indonesia Nomor.269/ MENKES/PER/III/2008 Tentang RekamMedis. Jakarta: Departemen Kesehatan RI.

Notoadmodjo, S. 2010. Metodologi Penelitian Kesehatan Edisi Revisi. Jakarta: Rineka Cipta.

Shofari, B. 2002. Pengelolahan Sistem Rekam Medis. Semarang:Perhimpunan Profesional Perekam Medis dan Informasi Kesehatan.

Sugiyono. 2002. Metode Penelitian Kuantitatif dan Kwalitatif. Yogyakarta: Aditya Pustaka.

Wijaya,T. 2010. Analisis Data Pengolahan Penelitian dengan Menggunakan SPSS. Yogyakarta: Atma Jaya

World Health Organization. 2004. Internasional Classification of Diseases and Related Health Problem Tenth Revision Volume 1.3. Geneva: WHO 